Indonesian Journal of Theology 2/1 (July 2014): 155-178

\title{
FENOMENA PEMBERHALAAN AGAMA
}

\section{Parulihan Sipayung}

\begin{abstract}
Religions tend to imprison God in their formulation. It is even not impossible that religions can replace God. The very act of replacing God is known as the idolatry of religion. Let God be God and religions be God's hands to bring liberation to the world.
\end{abstract}

Keywords: religion, idolatry, theology, violence.

\begin{abstract}
Abstrak
Agama cenderung memenjarakan Allah dalam rumusannya. Bahkan, bukan tidak mungkin kalau agama bisa menggantikan Allah - kalau ini terjadi, inilah yang disebut pemberhalaan agama - Biarlah Allah tetap menjadi Allah dan agama-agama menjadi tanganNya, membumikan pembebasan bagi dunia.
\end{abstract}

Kata-Kata Kunci: agama, berhala, teologi, kekerasan.

\section{Pendahuluan}

Berjuta-juta orang telah menempuh jalan beragama untuk mencari Yang Ilahi, namun ketika Sang Ilahi tidak ditemukan maka jalannya sering dijadikan sebagai allah. Inilah persoalan kini dalam hidup beragama. Agama secara eksklusif telah mengkampanyaken bahwa ajarannyalah satu-satunya yang benar, allah yang dikenal di luar ajarannya adalah allah palsu dan sesat. Yang Ilahi yang tidak terbatas telah dibatasi oleh agama yang terbatas.

Hal ini konkret dan faktual, sebagaimana telah dunia saksikan bersama-sama. Orang-orang yang beragama tanpa belas kasihan telah menghabisi nyawa orang lain atas alasan Deus vult (Allah menghendakinya/perang salib), sekelompok massa atas nama agama 
secara bringas telah memporak-porandakan perumahan dan mengubah teduhnya kedamaian menjadi ricuh, kacau, bahkan sampai menumpahkan darah. Ada juga yang secara militan menyatakan bahwa mereka adalah orang yang membela Yang Ilahi dan mau mati kapan saja walaupun kematiannnya menimbulkan penderitaan dan kematian bagi sesamanya.

Agama nyaris telah berubah fungsi. Karena perbedaan agama maka seseorang dapat diabaikan hak asasinya, agama telah menjadi penjajah nilai-nilai kemanusiaan. Hal ini adalah fenomena yang sangat memprihatinkan, itu mengapa penulis mengangkat tulisan ini dengan judul "Fenomena Pemberhalaan Agama."

Artikel yang ditulis dalam bingkai teologi agama ini handak menganalisa peran agama dalam ruang-ruang sosial, juga untuk memetakan bagaimana agama-agama berelasi dengan dengan allahnya, guna melihat apakah agama-agama berperan membumikan kebebasan, dan pada akhirnya berusaha meretas sebuah gagasan agar agama yang terbatas tidak lagi mengurung-membatasi Allah yang tidak terbatas dalam tiang-tiang ajarannya.

\section{Apa Itu Agama?}

Secara linguistik dari sudut pandang bahasa Indonesia agama berasal dari bahasa Sanskerta yaitu $a$ yang artinya tidak dan gama yang artinya kacau. Hal ini mengandung pengertian bahwa agama adalah suatu norma yang yang mengatur kehidupan manusia agar tidak kacau. ${ }^{1}$

Dalam bahasa Arab agama dikenal dengan nama al-din ${ }^{2}$ yang artinya dapat bermacam-macam seperti, al-mulk (kerajaan), al-kbidmat (pelayanan), Al-iiz (kejayaan), al-ichsan (kebajikan), al-ibadat (pengabdian) dan lain-lain. Dalam QS. Ali Imran: 85 juga disebutkan Hanya agama Islamlah yang diakui di sisi Allah, dan barang siapa yang mengakui agama yang bukan Islam sebagai agamanya maka tidak akan diterima dari pada-Nya. Jadi semua agama yang dianut para nabi

${ }^{1}$ H. Dadang Kahmud, Sosiologi Agama (Bandung: PT. Remaja Rosdakarya, 2000), 13, menurut inti maknanya yang khusus kata agama disamakan dengan religion (Inggris), religie (Belanda), semua berasal dari bahasa Latin yaitu religio, dengan kata dasar religare yang artinya mengikat.

2 Dalam Al-Qur'an, surat Al-Kafirun ayat 7, dikatakan demikian "bagimu al-din kamu dan bagiku al-din aku". Jadi kata al-din bisa meunjukkakn agama Islam atau agama lain. Tidak menunjuk pada agama yang sah. Jadi penggunaanya universal. 
itu adalah agama Islam. ${ }^{3}$ Jadi dalam sudut pandang Islam, agama adalah peraturan Tuhan yang tidak dapat dicapai dengan akal manusia melainkan dengan firmanNya.

Dalam perspektif Barat, keberadaan agama menekankan adanya pemisahan yang religius dan non-religius, istilah yang mereka pakai untuk ini adalah formative of the dichotomous. ${ }^{4}$ Sistem teistik Barat banyak dipengaruhi oleh agama Yahudi, Kristen dan Islam. Gaya paguyuban keagamaan Barat adalah "gathered people," yaitu a group of persons who have been divinely called to and have conciously chosen to follow this particular faith rather than other possible faith or non-faith. Keagamaan seperti inilah yang kemudian disebut oleh Friedrich Scleirmacher sebagai 'feeling of absolute dependence', absolute as contrasted to other, relative feelings of dependence.

Dari pemahaman di atas dapat disimpulkan bahwa agama secara etimologis (bahasa Sanskerta) adalah lembaga yang menjaga agar masyarakat tidak kacau. Artinya sebagai penjaga perdamaian. Agama ada sebagai bukti dari pengakuan manusia atas adanya sesuatu Yang Ilahi yang mengatur jagad raya ini. Hanya kepada Sang Ilahi-lah kita bergantung dan dalam pengamalannya ditunjukkan dengan hidup beragama, hidup menjaga ketidak-kacauan (tidak chaos).

\section{Lalu Berhala?}

Kata berhala diterjemakahkan dari idolatry, kata ini berasal dari dua kata Yunani yaitu, eidolon (image) dan latreia (adoration), jadi idolatry berarti adoration of images. Idolatry diartikan dengan beberapa hal yaitu penghormatan terhadap tokoh yang dianggap manusia super (Goblet d'Alviella), penghormatan pada objek tertentu dengan bergantung mutlak, dengan mempersembahkan sesajen, sebuah idol objek yang

${ }^{3}$ Mochtar Effendy, Ensiklopedi Agama dan Filsafat Jilid A-B (Palembang: Universitas Sriwijaya, 2000), 87. Berdasarkan pengklasifikasian ini agama dikelompokkan ke dalam dua bagian yaitu, agama wad'i (natural religion) dan agama samawi (revealed religion) atau disebut juga agama langit (samawi=langit). Perbedaan antara ke dua agama ini adalah bahwa ada anggapan bahwa agama samawi adalah pemberian dari Allah, yaitu ada wahyu yang datang dari Allah yang disampaikan nabi atau rasul, ada kitab suci, ada konsep Tuhan Yang Maha Esa, dan ada hidup sekarang dan akhirat sedangkan agama wad'i hal ini tidak ada (kalaupun ada maka sifatnya tidak terlalu lengkap).

${ }^{4} \mathrm{Hal}$ ini dijelaskan dengan, the basic structure of theism is essentially a distinction between a transcendent deity and all else, between the Creator and His creation and between God and man. Winaton L. King, "Religion", in Encyclopedia Of Religion Vol. III, ed. Mircea Elliade (New York: McMillan Library Reference, US, 1993), 282. 
biasanya berbentuk anthromorf yang diharapkan menghadirkan roh sebagai objek dari ritual dan lain-lain. ${ }^{5}$

Cristopher R. North menjelaskan ada dua ide mengenai berhala yaitu, "idolatry is the whorsip of the creature instead of the Creator and to make matter worse, the creature is made by man who is himself a creature." Jadi berhala adalah penyembahan kepada sosok idol yang adalah ciptaan manusia mengantikan Yang Ilahi. Setiap penyembahan kepada berhala seturut dengan pandangan North akan membawa kepada sesuatu yang semakin buruk karena manusia menyembah sesuatu yang adalah ciptaan manusia itu sendiri, menggantikan Sang Pengada yang sejati.

Jadi seturut dengan pendapat North, berhala dapat diartikan sebagai penyembahan kepada ciptaan yang dilakukan untuk menggantikan Sang Pencipta. Jadi setiap pemujaan pada buatan tangan manusia lalu meninggalkan Yang Ilahi, inilah yang penulis maksud dengan berhala.

\section{Hubungan Agama-Agama Dengan Yang Ilahi}

Allah adalah Dia yang universal dan tidak dapat dipahami dan dibahasakan. Manusia hanya dapat mengenal Allah jika Dia yang agung itu berkenan menyatakan diri dalam dunia. Meskipun Dia menyatakan diri tetap saja karena keterbatasannya, manusia tidak akan bisa memahami Dia secara utuh. Manusia tidak mengetahui apa-apa tentang Allah tanpa inisiatifNya dalam anugerah penyataanNya. Karena iman yang bertanggung jawab adalah iman yang tidak buta, sebuah credo ut intelligam yang artinya I believe in order to know. ${ }^{7}$ Dia Yang Ilahi itu telah menyatakan diri kepada manusia dengan berbagai cara. Allah menyatakan dirinya kepada Musa dalam bentuk api di atas gunung Sinai, Dia juga menampakkan dirinya kepada bangsa Israel dalam bentuk api dan awan saat dalam perjalanan di padang gurun, namun penampakanNya dapat pula sebagai merpati, atau sebagai sosok anthromorf.

Semua ini adalah model penampakan Yang Ilahi. Walaupun Yang Ilahi itu menampakkan diri dalam bentuk api belum tentu juga itu bisa menjadi dasar bagi kita untuk mengatakan bahwa api adalah Yang Ilahi, atau awan adalah Yang Ilahi. Karena semua itu hanya

\footnotetext{
5 Julien Ries, "Idolatry", in Encyclopedia Of Religion (Second Edition),ed. Lindsay James, (New York: Gale Cangage Learning, 2005), 4357.

6 Julien Ries, "Idolatry," 4357.

${ }^{7}$ Hans Küng, On Being A Christian (New York: Doubleday, 1968), 64-65.
} 
wujud penyataanNya saja. Dia tetaplah Dia dan Dia adalah misteri. Manusia hanya dapat belajar memahami Dia melalui penyataanNya.

Secara pluralis Ia telah menyatakan diri kepada banyak manusia dan manusia pun menanggapi penyatanNya itu. Jadi umat beragama harus menyadari bahwa semesta iman berpusat pada Allah dan bukan pada kekristenan atau agama lain pun, ia adalah matahari sumber awal dan terang kehidupan yang agama-agama refleksikan dengan caranya sendiri dan berbeda-beda. ${ }^{8}$ Agama-agama berhubungan dengan Yang Ilahi tapi dengan berbagai cara. ${ }^{9}$

Yang Ilahi adalah sumber segala kebaikan yang dari padaNya semua manusia dituntut untuk 'membumikan' kehendakNya. Secara umum semua agama mengajarkan tentang hal-hal yang baik dan tentu Yang Ilahi itu adalah sumber segala kebaikan. Knitter menyebutkan bahwa hubungan antara Yang Ilahi dengan agama-agama adalah ibarat analogi sumur dan air bawah tanah yang menjadi sumber atas semua air yang ada di permukaan. Sumur adalah agama dan mata air bawah tanah adalah Yang Ilahi, yang dari padaNya semua asal air sumur. Tidak ada sumur yang lebih baik airnya, karena semua air berasal dari sumber yang sama. Yang Ilahi itulah sumber segala yang baik dalam setiap agama. Yang terpenting dalam paham ini bukanlah Yang Ilahi itu sebagai persona atau supra persona, tapi yang terpenting adalah bahwa Yang Ilahi itu adalah sumber air religius tanpa dibatasi oleh konsep atau tradisi apapun. ${ }^{10}$

Wawasan agama-agama harus diganti dengan perspektif baru. Karena Yang Ilahi adalah sumber rahmat, kebaikan, keadilan, kedamaian, kesejateraan dll. Maka di mana ada rahmat di situ juga kerajaan Yang Ilahi hadir. ${ }^{11}$ Agama-agama adalah agen Yang Ilahi itu dalam menyapaikan pesan-pesanNya kepada dunia. Agama-agama harus bersatu padu membangun kerajaan Yang Ilahi. Karena Yang Ilahi adalah "induk" dari semua agama-agama maka seharusnya agama-agama menjadi partner kerja bagi agama yang lainnya dalam mewujud-nyatakan kehendakNya.

Pada awalnya agama-agama bersifat eksklusif dengan memahami bahwa Allah yang dikenalnya saja yang benar dan yang lain adalah palsu. Wawasan keagamaan yang sempit ini berkembang cukup lama dan pandangan ini gagal melihat bahwa dalam agama lain

${ }^{8}$ Joas Adiprasetya, Mencari Dasar Bersama (Jakarta: BPK-GM, 2002), 76. Petikan di atas adalah perkataan Jhon Hick.

${ }^{9}$ Denis L. Okholm, et.al, Four Views Of Salvation in A Pluralistic World (Michigan: Zondervan, 1995), 17. 2008), 149.

${ }^{10}$ Paul F. Knitter, Pengantar Teologi Agama-Agama (Yogyakarta: Kanisius,

11 Ibid., 230. 
pun ada sesuatu yang baik, artinya Yang Ilahi juga berkarya pada sesuatu yang baik di agama yang lain tersebut. Pendekatan untuk melihat bahwa ada sesuatu yang baik di agama lain baru diangkat kembali khususnya oleh gereja Katolik pada konsili Vatikan II. Konsili ini juga diawali dengan perjalanan panjang antara dua masalah kepercayaan yang fundamental dan kontroversial yaitu, kasih universal Allah dan kerinduanNya untuk menyelamatkan semua orang dan keharusan masuk gereja dahulu agar mendapat keselamatan. Pada Konsili Arles (473), gereja meghukum semua orang yang mengatakan, "Kristus, Tuhan dan penyelamat kita, tidak menjalani kematian untuk keselamatan semua orang" artinya bahwa Kristus tidak menginginkan bahkan satu orang pun binasa. Hal ini bertentangan dengan pemahaman Origenes (254) dan Cyprianus (258), mereka menyatakan bahwa out side the church, there is no salvation. ${ }^{12}$ Kedua konsep ini bertentangan dan sangat sulit diseimbangkan. Sejauh ini nampaknya gereja lebih mementingkan keutamaan gereja dari pada kasih universal Allah. Walaupun bapa-bapa gereja sepakat tentang finalitas Kristus sebagai juruselamat, tapi mereka juga sepakat bahwa wahyu sejati dan keselamatan juga ditawarkan bagi bangsabangsa lain (Although the early fathers of the church clearly beld to the uniqueness and finallity of Christ, they also endorsed a fairly common opinion that an authentic revelation and possibility of salvation was offered to all peoples). Justinus Martir, Clement dari Aleksandria, Origenes, Theofillus dari Anthiokia dan Athenagoras sepakat dengan seminal word (logos spermatikos), ${ }^{13}$ artinya ada nilai-nilai yang baik yang semua orang ambil bagian di dalamnya, semua orang yang memiliki nilai-nilai kebaikan ini, menurut Justinus sesunguhnya sudah menjadi kristen walaupun mereka belum pernah mendengar nama Yesus. Tertulianus menyebut istilah ini dengan dengan 'the naturally Christian soul' bahkan Agustinus menambahkan bahwa the one true religion existed "from the begining of

12 Paul F. Knitter, No Other Name? (New York: Orbis Books, 1985), $121-$ 122.

13 Ini adalah tesis dari Yustinus Martir, ia mengatakan, "Allah telah memberikan benih-benih kebaikan pada setiap rasionalitas manusia, jadi semua yang berakal baik dan melakukan perbuatan baik dapat dianggap sebagai anggota gereja”. Walaupun secara ide saya tidak sepakat dengan Yustinus karena ia tetap memutlakkan gereja sebagai "saluran utama" untuk bertemu Yang Ilahi. Ia tetap memutlakkan bahwa hanya gereja jalan satu-satunya bertemu dengan Yang Ilahi. 'Mungkin' ia juga terperangkap seperti sebagian orang yang memenjarakan Allah dalam gereja. Pemahaman Yustinus Martir sangat jelas bahwa siapa saja, bahkan mereka yang hidup sebelum Kristus yang pada masanya adalah manusia jahat dan memusuhi Allah, namun dibawah kuasa Firman, menurut kemauan Bapa yang adalah Allah segala yang ada, yang telah hadir sebelum Yesus, mereka telah diselamatkan. Don A. Pittman et.al, Ministry And Theology In Global Perspective (Michigan: William B. Erdsman Publishing Company, 1996), 68-69. 
mankind" dan lagi ia menambahkan bahwa anugerah yang menyelamatkan dari agama ini tidak pernah ditolak untuk diberikan kepada siapa saja yang menghargainya.

Dari sini dapat dipahami bahwa sebenarnya anugerah keselamatan dari pada Allah terbuka bagi agama-agama lain, ${ }^{14}$ karena Allah adalah awal dan akhir dari segala sesuatu. Bagi umat kristen dan cara yang berbeda bagi umat Yahudi, Islam dan Hindu, Allah yang dinyatakan tersembunyi dan tidak dapat dipahami, karena melampaui bagi pengertian dan kontrol manusia. Berbagai gambaran, simbol dan konsep membawa kita kepada pengalaman dan pengenalan akan Allah, namun hal-hal itu tidak dapat menggambarkan secara penuh realitas Allah. ${ }^{15}$ Konsili Vatikan II ini juga mengajarkan Roh Kudus aktif bekerja dalam seluruh kehidupan umat manusia menawarkan anugerah dan keselamatan kepada semua manusia entah mereka mengenal Yesus atau tidak. Karena keselamatan ditawarkan maka pastilah anugerah iman juga ditawarkan, iman adalah penerimaan terhadap penyataan. Dengan demikian jika iman dinyatakan pada semua orang maka Allah juga dinyatakan pada semua orang. Jadi penyataan juga ditemukan dalam agama-agama lain. Inilah dasar untuk mengakui bahwa jangakauan penyataan Allah meliputi seluruh ras manusia.

\section{Beberapa Pemikiran Kritis Tentang Agama}

\section{1) Skeptisisme, Agnostikisme dan Ateisme ${ }^{16}$}

Skeptisisme, skeptisisme berasal badi bahasa Latin yaitu, skepticus, artinya ragu, merenung dan mengandung pertanyaan. Kata Latin ini ditarik dari bahasa Yunani scepsis yang memiliki kesamaan makna. Pertama sekali sekolah skeptisisme ini dimulai sekitar tahun 365 SM. Filsuf skeptis pertama yang pernah tercatat adalah Pyrrho

14 Tuhan Yesus juga beberapa kali menekankan hal ini, bahwa Ia (dokter) datang bukan untuk orang sehat melainkan untuk orang sakit (Mat. 9: 12). Ia juga mengatakan bahwa kasih Allah begitu besar bagi seluruh dunia, karena itu ia merindukan agar semua orang selamat (Yoh. 3: 16). GM, 2003), 13

${ }^{15}$ Leo D. Lefebure, Penyataan Allah, Agama dan Kekerasan, (Jakarta: BPK-

${ }^{16}$ Josh McDowell, Don Stewart, Handbooks Of Today's Religion (London: Thomas Nelson Publishers, 1983),412-423 Walaupun pemikiran ini sudah muncul sebelum beberapa agama ada, bahkan ide-ide ini tidak berpapasan langsung dengan agama-agama Timur tapi saya mau tunjukkan bahwa gagasan pemikiran ini pada babakan waktu berikutnya banyak menjadi acuan bagi para pemikir dalam mengkritik Allah dan agama. 
dari Ellis 365-275 SM. Skeptisisme diadopsi sebagai jalan untuk menghindari kekacauan mental dan emosional dikarenakan oleh data yang tidak jelas. Premis fundamental dari pemahaman skeptis adalah mereka hanya dapat memahami satu hal yaitu tidak ada yang dapat diketahui. B.A.G. Fuller mengatakan bahwa peraturan skeptisime adalah pengingatan kembali pada manusia bahwa pengetahuan dengan kepastian mutlak adalah tidak mungkin. Artinya tidak ada kepastian kebenaran mutlak pada pengetahuan. Skeptisisme adalah ketidak-percayaan total akan segala hal menuju kepada keraguan sementara, dalam proses mencapai kepastian. Arcesialus megatakan bahwa jika seseorang tidak bisa memahami sesuatu, bahkan tentang agama, ia bisa membuat suatu kemungkinan dan ia akan diatur sepenuhnya oleh kemungkinannya tersebut. Menanggapi skeptisime ini Sokrates juga pernah mengatakan bahwa, "apa yang saya tahu adalah saya tidak tahu apa-apa". Namun Rene Descartes (1596-1650) seorang pemikir skeptis kristen mengatakan, bahwa skeptisisme adalah alat untuk membuktikan keberadaan Allah, bahwa Allah adalah sesuatu yang tidak terjangkau dan tidak dapat ditemukan oleh akal manusia.

Kedua agnotisme, kata ini berasal dari bahasa Yunani $a=$ tidak dan gnosis $=$ pengetahuan (biasanya melalui pengalaman). Agnostis memahami bahwa peristiwa tidak cukup untuk membuktikan atau tidak membuktikan ada atau tidak adanya Allah. Sehubungan dengan eksistensi Allah Runnes mengatakan bahwa tidak mungkin bagi manusia untuk memahami Allah. Manusia tidak mengkin bisa membuktiakn apakah Allah itu ada atau tidak ada. Agnostis terbagi dalam dua bagian yaitu soft agnostic dan hard agnostic. Soft agnostic memahami bahwa manusia tidak tahu apakah Allah ada, tapi bukan hal mustahil juga untuk mengetahui bahwa Allah ada. Hard agnostic memahami, adalah hal yang tidak mungkin untuk mengetahui apakah Allah itu ada atau tidak. Bagi golongan ini berbicara tentang Allah adalah meaningless atau nonsens (tidak berarti) karena manusia tidak dapat mengetahui Allah. Menurut agnostis yang manusia dapat pahami adalah sesuatu yang ada dalam dunia nyata, melalui pengalaman empiris, melalui indra perasa dan pikiran manusia. Perbedaan antara skeptisime dan agnotisme menurut Warren Young adalah skeptisisme membawa manusia pada sikap negatif selangkah lebih jauh dari pada agnotisme, skeptisisme juga meniadakan kemampuan dari pengatahuan manusia.

Ateisme, kata ini berasal dari kata Yunani yaitu $a=$ tidak, theos $=$ allah. Atheisme melihat bahwa ada keadaan yang positif dengan tidak adanya Allah. Artinya bagi golongan ini segala kejadian dapat diterangakan secara alami, tapa campur tangan yang supra-natural. 
Kaum ini memahami bahwa semua bentuk keimanan, agama dan peristiwa Ilahi adalah palsu. Menurut Plato ada dua jenis atheis yaitu paham yang meyakini bahwa Allah benar-benar tidak ada (atheis moralis yang menekankan kejujuran) dan paham yang satu lagi mengatakan bahwa tidak ada tempat bagi Allah di dunia ini (atheis anarkis, tanpa aturan dan mengancam masyarakat). Atheisme sebagai sistem kepercayaan baru diperkenalkan kembali oleh Niccolo Machiavelli (1527), ia memperkenalkan etika sosial tidak bergantung pada eksistensi Allah.

Ide dari ke tiga hal ini telah lama ada dan ke tiganya berakar kuat dalam budaya Yunani. Dari sini dapat dilihat bahwa kritik tentang keberadaan Allah telah lama jadi bahan perdebatan. Hal yang mau saya angkatkan adalah bahwasanya konsep 'pembentukan' dan 'pengaturan' tentang apa dan bagaimana segharusnya allah telah lama dibahas dan dari sini pulalah mulai tumbuh patung konseptual yang diciptakan manusia tentang bagaimana seharusnya Allah yang diinginkannya.

\section{2) Kritik Karl Marx: Religion As Opium Of The People}

Dalam tesisnya Marx mengatakan bahwa manusialah yang membuat agama bukan agama yang membuat manusia. Agama adalah tanda keterasingan manusia dari dirinya sendiri. Karena agama adalah perealisasian manusia dalam angan-anganya saja. Jadi ini adalah tanda bahwa manusia belum berhasil merealisasikan hakikatnya. Agama adalah sebuah pelarian dari realitas manusia. ${ }^{17}$

Bagi Marx agama adalah kekuatan sosial. Ia melihat agama sebagai "candu masyarakat," yang membawa ilusi kebahagiaan tetapi bukan kebahagiaan sejati, dan menyebabkan manusia memusatkan perhatian pada kehidupan abadi, bukannya yang sekarang.

Marx melihat bahwa agama adalah alat yang diciptakan oleh orang-orang yang memiliki kewenangan untuk melanggengkan kekuasaannya. Propaganda inilah yang disebutnya sebagai candu bagi masyarakat. Marx mengkritik agama Kristen yang telah mempropagandakan etika ketertundukan, dimana di dalamnya manusia hanya bisa tunduk terhadap segala aturan yang dilegitimasi sebagai aturan dari Allah. Manusia pasif dan menerima penderitaan sebagai karunia, sebagai sarana untuk mencapai kebahagiaan kekal. Ini mengindikasikan bahwa manusia akhirnya hanya bisa menerima penderitaannya dan tidak berbuat apa-apa. Justru sikap tunduk inilah

17 Franz Magnis-Suseno, Pemikiran Karl Marx (Jakarta: PT. Gramedia Pustaka Utama, 2003), 72-73 
yang menguntungkan kaum kapitalis yang nota bene menguasai roda perekonomian. Dalam konteks ini Marx melihat bahwa agama adalah ekspresi langsung dari kelas yang berkepentingan, kelas yang dominan secara ekonomi bahkan politik yaitu kelas kapitalis.

Kritik Marx terhadap agama bagi penulis berakar dari pemberhalaan terhadap agama pada masa itu. Sebagaimana disebut Cristopher R. North di atas: "idolatry is the whorsip of the creature instead of the Creator, - the creature is made by man who is himself a creature." Agama sebagai ciptaan manusia telah diperalat guna melaksanakan maksudmaksud golongan tertentu, bahkan elit ini tidak segan-segan menggunakan nama Allah - etika keagamaan - guna menundukkan masyarakat. Kritik agama yang dilancarkan oleh Marx sebenarnya merupakan langkah awal memasuki kritik masyarakat. Bagi Marx, kritik agama tidak akan mengubah keadaan manusia yang menderita. Yang dibutuhkan adalah kritik masyarakat, agar agama (yang mengurung Allah) tidak lahir. Dengan demikian, dapat dikatakan di sini bahwa kritik surga menjadi kritik dunia, kritik agama menjadi kritik hukum, dan kritik teologi menjadi kritik politik.

\section{Radikalisme Agama}

Ketika agama tadi telah dikuasai oleh oknum tertentu, dalam lapisan masyarakat, maka tidak jarang penunggang agama tersebut demi mewujudkan ambisinya melakukan tindakan-tindakan radikal. Memang akar dan alasanya dalam panggung historis empiris dapat beririsan dengan banyak isu dan kepentingan, tapi tidak dapat dielakkan bahwa pemberhalaan agama di atas turut membidani radikalisme agama.

Radikalisme agama adalah pembenaran dalam melakukan kekerasan atas nama agama. Alasan ini tentu tidak terlepas dari adanya sikap fanatis dan fundamentalis, ${ }^{18}$ yang tinggi dan tidak

18 Bagi kaum fundamentalisme kata ini adalah ejekan dan mereka lebih suka dengan sebutan evangelikal konservatif. Paham tantang fundamentalisme ini sangat luas dan beragam. Namun ada beberapa hal yang secara umum dapat mencirikan sikap mereka yaitu:

1. Penekanan yang sangat kuat terhadap ketidak bersalahan (inerrancy) Alkitab.

2. Kebencian yang mendalam terhadap teologi modern dan metode, hasil dan akibat dari studi kritik modern terhadap Alkitab.

3. Jaminan kepastian bahwa mereka yang tidak ikut manganut pandangan keagamaan mereka, bukanlah 'kristen sejati'.

James Barr, Fundamentalisme (Jakarta: BPK GM, 1996), 1-3 
terkendali. Sikap fundamentalis ini dihubungkan dengan dua sikap yang sangat mencolok yaitu sikap ekstrimis dan sikap puritan yang bertumpu pada pemurnian agama. Fundamentalisme dicirikan sebagai pembelaan dan kesetiaan yang teguh dan militan atas seperangkat dasar-dasar iman. ${ }^{19}$ Orang-orang fundamentalis biasanya adalah orang-orang yang konservatif dan eksklusif, sektarian dan cenderung mencurigai kelompok agama lain. Sikap ini membagi dunia atas dua bagian yaitu yang selamat dan kafir, yang terang dan yang gelap. Penyataan Alllah dipahami hanya milik kaumnya dan kaum lain adalah orang sesat seingga harus diterangi dan dalam upaya penerangan ini maka kekerasan dan penghancuran pun dibenarkan. ${ }^{20}$

Beberapa kasus mengenai radikalisme agama dapat dilacak dalam sejarah, salah satu hal dalam sejarah gereja adalah keputusan Paus Inocentius IV (1252) yang pemahamannya banyak dipengaruhi oleh Cyprianus yang menggemakan Extra Ecclesiam Mulla Salus. Ia menyatakan bahwa pemurtad-pemurtad yang tidak mau bertobat dijatuhi hukuman ekskomunikasi, pemenjaraan, penyitaan harta milik, atau dibakar hidup-hidup. ${ }^{21}$ Mereka diarahkan untuk melihat dunia non-Kristen sebagai kumpulan orang kafir yang belum bertobat, yang akan masuk neraka kecuali mereka dibaptis dan menerima satusatunya perantara keselamatan yaitu gereja Katolik. Cara pandangnya adalah bahwa gereja memiliki Roh dan mereka memiliki dosa dan kekafiran. ${ }^{22}$ Radikalisme ini berkembang pada era perang salib di mana para prajurit dengan tanpa rasa kemanusiaan mencabut nyawa orang lain atas nama agama. Bahkan ada anggapan bahwa membunuh dalam perang salib itu bukanlah kejahatan tapi merupakan pahala karena telah berjuang di jalan allah.

Sejarah pahit dari pembantaian orang Yahudi oleh Nazi masih menimbulkan luka sejarah yang mendalam sampai saat ini. Hanya kerena mereka suku dan beragama Yahudi maka ribuan dari mereka

Nuansa pemahaman yang fundamental juga dapat dilihat dalam masa awal Gereja Katolik Roma dimana Paus di Roma mengatakan bahwa:

1. Ia memiliki kekuasaan tertinggi atas seluruh gereja.

2. Keinginan Roma untuk diakui oleh seluruh gereja di seluruh dunia dan

3. Perubahan yang dilakukan Roma atau bunyi kredo tidak dapat diganggu gugat oleh umat Kristen Timur.

Michael Keene, Agama-Agama Dunia (Yogyakarta: Kanisius, 2006), 96.

${ }^{19}$ Jan S. Aritonang, Belajar Memahami di Tengah Realita(Bandung: Jurnal Info Media, 2007), 155

20 Jhon Renis Saragih, "Radikalisme Agama, Antara Kekerasan Dan

Perdamaian", Jurnal Teologi Tabernakel STT Abdi Sabda Medan, No. 22 (Juli Desember 2009): 32

${ }^{21}$ John Stott, Isu-Isu Global Menentang Kepemimpinan Kristiani (Jakarta: YKBK OMF, 1994), 54.

22 Paul F. Knitter, Satu Bumi Banyak. Agama (Jakarta: BPK GM, 2002), 4-5 
dimusnahkan seperti sampah. Salah satu kisah pahit dari kota Tserkov, Ukraina adalah sekitar 3000-5000 dari orang Yahudi dewasa ditembak, dan terdapat juga sekitar 90 anak yang masih bayi, semua dibunuh dan dikubur dengan truk. ${ }^{23}$ Dalam sejarah Islam ada sebuah kelompok radikal yang pertama kali memberikan label kafir pada sesamanya Islam, yaitu kaum Khawarij. Mereka telah mengesampingkan pesan akal dalam menafsirkan pesan-pesan wahyu, mereka menafsirkan kitab suci secara harfiah (literal-legalistik). Abdulrahman Wahid melihat kelompok ini sebagai akar radikalisme yang menurunkan paham yang suka menafsirkan Al-Qur'an dan Hadits secara harfiah dan tertutup, suka mengkafirkan siapapun yang berbeda dari mereka dan tidak segan-segan membunuh siapa saja yang telah dianggap kafir. ${ }^{24}$

Hal yang hangat yang dapat disaksikan adalah mengenai kasus Ahmadiah yang menelan korban jiwa, korban luka-luka, kerusakan dan kerugian-kerugian lainnya. Hal ini tentu sangat memprihatinkan. Agama yang seharusnya menjadi pemelihara perdamaian telah menjadi hakim untuk membinasakan. Agama telah menjadi alat ukur, kadar kebenaran mutlak.

\section{Agama Sebagai Berhala}

Allah tidak menyingkapkan teologi, Ia menyingkapkan diriNya sendiri. Setiap sistem atau gagasan teologis adalah sebuah tanggapan, ia terbatas, ia fana dan hanya sekedar hasil bangunan

23 Proses eksekusinya dilakukan dengan cara yang sangat kejam, di mana anak-anak diturunkan dari truk lalu tentara Nazi berdiri mengelilingi anak-anak ini dan mereka ditembak sambil berjatuhan ke dalam lubang tempat mereka langsung terkubur. Mengingat kejadian ini banyak orang menjerit kalau memang Allah itu ada maka di manakah Dia pada saat itu? Manusia menjerit di manakah Allah? Namun sesungguhnya ini adalah jeritan Allah juga. Allah dengan sedih memanggil agamaagama, sama seperti Ia memanggil "Kain, Kain, Kain, di manakah saudaramu Habel, apa yang kamu lakukan terhadap dia?" Ini jugalah panggilan Allah terhadap agama-agama. Apa yang telah kau lakukan terhadap sesamamu, apa yang telah engkau lakukan terhadap dia. Jurgen Moltmann, God For A Secular Society (Minneapolis: Fortress Press, 1999), 170-189.

${ }^{24}$ Kaum ini adalah kaum Khawarij. Kaum yang pada awalnya mendukung Ali ibn Abu Thalib dalam perang melawan Mu'awiyah. Namun kaum ini keluar dari barisan Ali karena tidak sepaham dengan kesepakatan antara Ali dan kelompok Mu'awiyah pada saat itu. Karena bagi kelompok ini kesepakatan manusia telah mencemari hukum allah. Allah-lah yang menentukan hukum bukan manusia. Jadi kelompok ini tidak mengakui adanya peran akal manusia dalam menafsirkan perintah allah. Abdulrahman Wahid, Ilusi Negara Islam; Ekspansi Negara Islam Transnasional di Indonesia (Jakarta: PT. Desantara Utama Media, 2009), 60-61. 
manusia. ${ }^{25}$ Jadi teologi adalah patung konseptual tentang Allah. ${ }^{26}$ Tapi agama dan teologi juga tidak sepenuhnya salah karena itu mereka juga dapat disebutkan sebagai perantara-perantara fana antara umat manusia dengan Allah. Oleh karena itu kelirulah kalau agama diidentifikasikan sebagai kebenaran mutlak atau Allah. Karena kalau agama atau rumusan tradisi disamakan dengan Allah maka agama itu telah menjadi berhala dan allah telah dikurung dalam rumusan itu. Sehingga agama menggantikan Allah. Sungguh kelirulah jika kita menganggap agama sebagai suatu patokan kebenaran yang mutlak, karena agama ibarat jendela yang Allah buat agar manusia bisa mengenalnya dan pengenalan itu tidaklah mutlak. Karena apa yang dinyatakan kepada manusia adalah sebagian dari diriNya. Jadi adalah keliru jika manusia memberikan penghormatan kepada jendela itu melebihi dari pada yang dibalik jendela itu. Jendela itu telah menggantikan Dia yang membuat jendela itu. Ini keliru, yang harus dilakukan adalah menembus jendela menuju kepada Allah. Jendela adalah respon manusia terhadap penyataan Allah, jadi alangkah lucunya kalau jendela yang dibentuk oleh manusia itu dianggap sebagai tujuan final. Hal ini lah yang saya sebut sebagai berhala, di mana yang terbatas telah menggantikan yang tidak terbatas. Jadi penyembahan berhala dapat juga disebutkan sebagai memperlakukan secara keliru sesuatu yang fana seolah-olah hal itu bersifat Ilahi. ${ }^{27}$

Harus dipahami juga bahwa bukan penyataan itu yang dianggap berhala di sini tapi konsep manusia tentang penyataan itu, yang dianggap melebihi Yang Ilahi yang adalah oknum yang menyatakan penyataan itu, itulah yang disebut berhala. Kenapa

${ }^{25} \mathrm{Hal}$ ini sejalan dengan apa yang dikataka Karl Marx. Dalam tesisnya ia mengatakan bahwa manusialah yang membuat agama bukan agama yang membuat manusia. Agama adalah tanda keteransingan manusia dari dirinya sendiri. Karena agama adalah perealisasian manusia dalam angan-anganya saja. Jadi ini adalah tanda bahwa manusia belum berhasil merealisasikan hakikatnya. Agama adalah sebuah pelarian dari realitas manusia. Franz Magnis-Suseno, Pemikiran Karl Marx, 72-73

26 Wilfred Cantwell Smith, "Pemberhalaan Dalam Persepektif Perbandingan", dalam Mitos Keunikan Agama Kristen, ed. Jhon Hick dan Paul F. Knitter (Jakarta: BPK GM, 2001), 89.

${ }^{27} \mathrm{Hal}$ ini juga ditemukan dalam agama Hindu yaitu sekitar tahun 800-500 sM. Pada zaman ini para Brahmana mendapat peran yang sangat berkuasa dan sentral. Bahkan meraka dinggap satu-satunya oknum yang dapat memaksa para dewa untuk memenuhi keingingan manusia melalui persembahan kurban. Para Brahmana satu-satunya orang yang mampu menafsirkan kitab Weda bahkan kedudukan mereka dingkat begitu tinggi dengan sebutan dewa insani. Umat Hindu tidak dapat bertemu dengan dewa atau Yang Ilahi tanpa melalui para Brahmana. Dengan demikian para dewa secara tidak langsung hanya mengasihi dan mendengarkan para Brahmana saja. Dalam pandangan saya Brahmana telah mengurung para dewa sesuai kehendaknya dan inilah pemberhalaan. Band. A. G. Honig, Jr, Ilmu Agama (Jakarta: BPK GM, 2005), 95-96. 
dikatakan agama sebagai berhala karena dalam perjuangan mencapai tujuannya agama telah beralih fungsi, dalam menciptakan masyarakat yang adil. Agama-agama kerap kali berada di bagian yang kuat dan berkuasa, bukan pada yang miskin dan tertindas, agama sering menjadi 'bumbu yang sedap' dalam dunia politik. Agama telah beralih fungsi. Norma agama sering diuniversalkan dengan demikian agama lain dihakimi dengan normanya itu dan penindasanpun tidak terelakkan lagi. Agama adalah berhala jika tidak sampai pada pembicaran dan aksi memanusiakan manusia, dengan memberantas kemiskinan dan penindasan yang merajalela. Agama (khususnya kristen) seharusnya tidak bersikap partikularis. Allah sendiri menunjukkan sikap yang pluralis mengapa agama harus bersikap partikularis. Bahkan yang partikular di dalam Dia, Dia telah menyalibkan yang partikular itu untuk kepentingan yang universal. Demikian seharusnya agama-agama menilai dirinya, bersikap partikular namun bebas dari partikularis, religius namun bebas dari fundamentalisme agama. ${ }^{28}$

Dengan judul ini saya bukannya mau mengangkatkan bahwa agama itu tidak perlu tapi ide saya adalah gagasan tentang agama ini harus ditinjau ulang. Agama adalah lembaga penjaga perdamaian agar tidak terjadi kekacauan. Agama adalah sarana pembebasan Allah, tapi ia bukan Allah. Kasih karunia Allah harus dinyatakan oleh agama. Agama yang beraksi, memimpin kepada keadilan dan kesejahteraan. Karena agama adalah salah satu tempat di mana Allah telah menyatakan diri dan di mana Allah hadir menyatakan diri maka di sana ada damai sejahtera.

Hal ini tentu berbeda dengan fenomena yang terjadi belakangan ini, di mana kehadiran agama telah menjadi ancaman bagi masyarakat lain yang beragama lain. Manusia tanpa belas kasih membunuh atas nama agama. Bahkan pembenaran kekerasan dilakukan demi memusnahkan agama yang berbeda yang dianggap kafir dan bila hal itu berhasil maka hal itu dianggap menyukakan hati Allah dan ini bisa mempermulus perjalanan ke sorga. Jika kita kembali ke masa lalu, maka di mana kekristenan hadir pasti di sana ada kolonialisme, ada 'pembumian' budaya Barat, ada klaim yang mengatakan bahwa kekristenan adalah kebenaran mutlak.

Kehadiran kekristenan di Sumatera telah menghilangkan banyak budaya Sumatera. Kesadaran sebagai pemeluk satu agama ini juga mempersempit kesadaran sebagai mahluk ciptaan Tuhan, bagi masyarakat tertentu sesamanya manusia adalah sesama agamanya, yang lainnya adalah kafir bukan manusia baik, tapi adalah orang sesat

\footnotetext{
${ }^{28}$ Harold Coward, Pluralisme, Tantangan Bagi Agama-Agama (Yogyakarta: Kanisius, 1989), 56
} 
yang harus ditobatkan bahkan dengan kekerasan sekalipun, menurut ukuran norma agamanya. Karena Allah yang benar hanya milik agamanya, Allah itu telah ia penjarakan dalam agamanya, yang tidak terbatas telah ia batasi sesuai kehendaknya. Allah telah menjadi budak agamanya yang hanya melakukan apa yang dikehendaki oleh pemeluk agama tersebut. Agama yang seperti inilah yang saya maksud sebagai berhala, artinya agama ini bukanlah Yang Ilahi, tapi ia telah menggantikan Yang Ilahi. Bagaimana Allah itu adalah bagaimana adanya Ia dipikiran manusia. Karena itu tanpa ia sadari ialah yang menbentuk Allah. Hal ini ibarat perbincangan Allah pada mulanya yang kemudian diadopsi menjadi pembicaraan manusia, yaitu manusia berkata, "marilah kita menciptakan Allah sesuai dengan gambar dan rupa kita. .." (Kej. 1: 26)

Hal lain yang saya lihat bahwa semakin banyak agama yang tampaknya dunia semakin kacau. Ini adalah pertanyaan apakah agama-agama ini benar-benar masih menjalankan kehendak Yang Ilahi atau rumusan manusia. Karena dengan sikap agama-agama sekarang Allah telah menangis. Sikap agama-agama sekarang mempertontonkan seakan-akan Allah itu adalah Allah yang menyukai kekerasan, karena agama kerap kali dipakai sebagai panglima perang, bahkan umat yang taat beragama di satu pihak namun di pihak lain ia menjadi orang yang kejam yang membunuh atasa nama Allah. Sikap agama-agama kini telah menunjukkan adalanya pola pembangkangan terhadap Allah, bahkan jauh lebih parah Allah yang empunya dunia dan agama secara sadar atau tidak telah didepak dari dalamnya. Agama yang merupakan sistem kepercayaan yang di dalamnya ada tuntutan untuk hidup dalam kebenaran Allah telah diubah menjadi Allah.

Idealnya harus dibangun kekristenan tanpa religi. Karena religi adalah gagasan, rumusan, tanggapan yang berpusat pada usaha manusia untuk bertemu dan berdamai dengan Allah. Namun tentu jelas dipahami bahwa manusia tidak dapat menjangkau dan mengetahui apa dan bagaimana Allah. Manusia hanya bisa belajar mengenal Allah kalau Dia rela menyatakan diri-Nya dan hadir dalam kehidupan manusia, kalau pun Dia menyatakan diri manusia yang terbatas itu, pasti juga tidak dapat mengerti penyataanNya itu secara utuh. Namun faktanya adalah agama seakan-akan telah mengenal Allah itu secara mutlak dan agama-agama menghadirkan sejumlah aturan moral sebagai syarat yang harus ditempuh untuk memperoleh keselamatan, aturan itu sendiri diklaim agama berasal dari Allah jadi keselamatan itu tidak lagi berpusat pada Allah tapi berasal dari usaha manusia dalam menjalankan aturan agama itu. Oleh karena itu pemeluk agama nampaknya memisahkan diri dari dunia sekuler dan 
asyik ritual dalam agamanya. Allah dianggap hanya menghadapkan wajahnya pada agama tertentu dan menyatakan bermusuhan dengan dunia sekuler. Ini meyebabkan agama tidak menjadi fungsional, agama telah menjadi tempat penyemaian separatisme. Bukankan seharusnya agama harus menyatakan pesan Allah pada dunia? bukan malah memalingkan wajah dan berdiam diri melihat penderitaan dunia.

Sebuah pertanyaan baru harus diangkatkan, andaikata kalau manusia tidak ada, apakah Allah ada? Alkitab adalah tanggapan manusia atas pengalamannya atas penyataan Allah. Karena kita harus memandang kitab-kitab tiap umat beragama bukan sebagai biografi atau data-data lengkap tentang Allah, tapi kitab suci itu adalah pengakuan iman para penulis Alkitab tentang Allah. Allah yang sesungguhnya tidak terjangkau oleh kitab-kitab manapun. Karena Allah adalah misteri yang tidak terselami dan tidak terbahasakan oleh logika manusia. Namun karena tidak ada sumber lain yang memperkenalkan Allah pada manusia kecuali kitab-kitab suci tersebut maka kitab-kita itu menjadi dimutlakkan menjadi dasar ukuran kebenaran tentang Allah. Padahal kalaulah semua karya Allah, tentang apa dan bagaimana Dia pasti kitab-kitab itu sendiri tidak sanggup memuat tentang Dia yang maha besar itu. Bahkan seluruh dunia ini tidak cukup untuk menuliskan tentang siapa Allah. Oleh karena Allah adalah universal. Maka agama yang menyempitkan siapa Allah itu, agama yang hidup dalam ajaran keselematan pada wawasan sempit dan partikularisme adalah wujud pembangkangan terhadap Allah. Agama telah menjadi berhala dan menyatakan diri bermusuhan dengan Allah. Allah bukan made in agama apa pun. Seperti yang disebutkan Paus Fransiskus dalam Harian Kompas pada tanggal 8 Oktober 2013, "Saya percaya akan Tuhan, tetapi bukan (kepada) Tuhan Katolik, Tuhan bukan Katolik. Tuhan adalah universal." Allah adalah universal dan tidak dikuasai oleh apapun. Jadi biarkanlah Allah tetap menjadi Allah, Allah yang bebas dari komando agama dan hendaknyalah agama kembali kepada fungsinya yang mempersaksikan bahwa Allah itu baik pada semua orang. Mengenai keselamatan biarlah itu menjadi urusan Allah, agama tidak perlu turut campur dengan itu, yang harus agama-agama lakukan adalah pembebasan, bebas dari kemiskinan, penderitaan, agama yang peka pada masalah manusia dan bergumul memberikan pertolongan sebagaimana Allah melakukannya, dengan demikan agama akan menjadi agama yang beradab.

Jadi agama menjadi berhala bila agama diidentifikasikan sebagai kebenaran mutlak, seakan-akan agama adalah Allah. Agama adalah respon manusia akan penyataan Allah, dalam agama respon- 
respon itu dirumuskan dan ditradisikan. Karena kalau agama atau rumusan tradisi tadi disamakan dengan Allah, kama agama tersebut telah menjadi berhala dimana Allah terkurung di dalam rumusannya.

\section{Pandangan Teologi Kristen}

Amos dalam zamannya sangat keras mengkritik seremonialisme peribadahan bangsa Israel. Kritik tajamnya antara lain muncul dalam Amos 5:21-24:

Aku membenci, Aku menghinakan perayaanmu dan Aku tidak senang kepada perkumpulan rayamu. Sungguh, apabila kamu mempersembahkan kepada-Ku korban-korban bakaran dan korban-korban sajianmu, Aku tidak suka, dan korban keselamatanmu berupa ternak yang tambun, Aku tidak mau pandang. Jauhkanlah dari pada-Ku keramaian nyanyiannyanyianmu, lagu gambusmu tidak mau Aku dengar. Tetapi biarlah keadilan bergulung-gulung seperti air dan kebenaran seperti sungai yang selalu mengalir.

Keil dan Delitzsch mengatakan bahwa sistem keagamaan ini adalah outward and heartless worship. ${ }^{29}$ Dalam praksisnya tidak ditemukan misphat dan tsedaqah dalam perayaan yang menggebu-gebu tidak terimplementasi keadilan yang bergulung-gulung seperti air dan kebenaran yang seperti sungai selalu mengalir.

Dalam riset Jontor Situmorang pada kitab Amos, kata $t s^{e}$ daqah sering berpasangan dengan mishpat. Mishpat berarti: kebenaran (righteousness), yang benar dan layak (what is right and proper), pengatur dunia (world order), hasil karya Allah (Maz. 111:7) dan perintah dari mulut Allah (Maz. 119:13). ${ }^{30}$ Menurut Ludwig Koehler dan W. Baumgartner sebagaimana dikutip oleh Jontor Situmorang, mishpat bermakna paralel dengan torah. ${ }^{31}$ Kata ini juga memiliki makna menghukum tapi untuk tujuan positif yakni dalam rangka restorasi dan pendisiplinan. ${ }^{32}$ Misphat dan ts daqah saling berhubungan dan sifatnya saling melengkapi (interchangeably).

${ }^{29}$ C. F. Keil dan F. Delitzcch, Commentary of The Old Testament. 10 Volumes, (Edinburgh: T \& T Clark, 1866).

${ }^{30}$ Jontor Situmorang, The Understanding of Mispat and Sedaqab in the Book of Amos and Its Implication in Indonesia: (Ph. D, Diss. Cheonan: Hoseo University, 2004), 61.

31 Ibid., 61.

${ }^{32}$ Situmorang, Understanding of Mispat and Sedaqah, 61. 
Sedangkan ts daqah paralel dengan 'munah yang artinya kesetiaan. ${ }^{33}$ kata $t s^{e} d a q a b$ ini berarti kesetiaan pada komunitas, dimana TUHAN bertindak memelihara kedamaian (preservation of good order) dengan menyingkirkan hal-hal yang dapat merusak kedamaian (eliminating all that breaking peace). ${ }^{34}$ Ts daqah adalah hukum Allah. Dimana Allah bertindak untuk meyelamatkan dan menegakkan hal yang benar (rescues and sets to right). Kata $t s^{e} d a q a b$ dalam teks lain paralel dengan $t$ syu'ah (Yes. 46:12-13; 51:6; 56:1), dengan kata shalom (Yes. 54:14), dan dengan kata, khesed (103:17), dengan kekayaan (Ams. 8:18, wealth: hun), kesejahteraan (prosperity: Yoel 2:23). ${ }^{35}$

Jadi perayaan keagamaan tanpa praksis - meminjam istilah Eka Darmaputra - kebangkitan agama dan keruntuhan etika. Merupakan sistem keagamaan yang keliru. Dimana di dalamnya bukan lagi aturan Allah yang menjadi nadi keberagamaan tapi beralih menjadi aturan manusia.

Dalam Perjanjian Baru Yesus mengkritik ideoligisasi dan politisasi yang dilakukan oleh elit Yahudi. Dalam Matius 21:12-13 disebutkan:

Lalu Yesus masuk ke Bait Allah dan mengusir semua orang yang berjual beli di halaman Bait Allah. Ia membalikkan mejameja penukar uang dan bangku-bangku pedagang merpati dan berkata kepada mereka: "Ada tertulis: Rumah-Ku akan disebut rumah doa. Tetapi kamu menjadikannya sarang penyamun."

Dalam konteks peristiwa ini banyak pejiarah datang ke Yerusalem, dalam peribadahan para pejiarah ini harus mempersembahkan kurban. Kurban persembahan itu dapat dibeli didekat Bait Suci, dengan harga yang cukup mahal dan dengan mata uang yang berlaku di Yerusalem, tentunya para pendatang harus terlebih dahulu menukar mata uang mereka kemudian membeli korban persembahan. Dalam transaksi inilah terdapat banyak sekali kecurangan bahkan pemerasan. Craig S. Keener

${ }^{33}$ Kesetiaan yang dimaksud sangat dalam maknanya yaitu, tetap hati, teguh, stabil (stediness), dapat dipercaya (reliability), jujur (honest), setia (faitfullness) dan aman (security). William L. Holladay, A Concise Hebrew and Aramaic Lexicon of the Old Testament, (Michigan: WM. B. Eerdmans Publishing Company, 1980), 19

34 Situmorang, Understanding of Mispat and Sedaqah, 63.

${ }^{5}$ Norman H. Snaith, The Distinctive Ideas of the Old Testament, New York: Schoken Books, 1969), 62 
menyebutkan praktek ini sebagai: economic exploitation under the guise of religion. ${ }^{36}$

Dalam narasi lain dalam kitab Matius 15:3-6, Yesus berbicara kepada orang Farisi dan Ahli Taurat.

Tetapi jawab Yesus kepada mereka: "Mengapa kamu pun melanggar perintah Allah demi adat istiadat nenek moyangmu? Sebab Allah berfirman: Hormatilah ayahmu dan ibumu; dan lagi: Siapa yang mengutuki ayahnya atau ibunya pasti dihukum mati. Tetapi kamu berkata: Barangsiapa berkata kepada bapanya atau kepada ibunya: Apa yang ada padaku yang dapat digunakan untuk pemeliharaanmu, sudah digunakan untuk persembahan kepada Allah, orang itu tidak wajib lagi menghormati bapanya atau ibunya. Dengan demikian firman Allah kamu nyatakan tidak berlaku demi adat istiadatmu sendiri.

Ini merupakan bentuk penyimpangan terhadap keagamaan, di mana agama dipakai sebagai topeng untuk mewujudkan tujuan kelompok atau golongan tertentu.

Bukankah hal seperti ini juga yang dengan keras dikritik para Reformator, atas status quo yang terjadi sepanjang abad Pertengahan, tentang infalibilitas Paus, tentang indulgensia, tentang extra ecclesiam nulla sallus dan klaim-klaim sepihak yang pesannya seakan-akan agama itulah Allah, seakan-akan Allah hanya dimiliki oleh elit tertentu. Agama telah mengurung Allah dan agama diwakili oleh golongan tertentu untuk mencapai maksud-maksudunya.

Dalam perkembangan kemudian, teolog Asia yang dengan mengagumkan memetakan pemikiran Kristen mengarungi persoalan ini adalah Choan Seng Song, ia meyebutkan:

Teologi Kristen telah menjadikan Allah yang tersembunyi ini terlalu tembus pandang; ia telah membuat kita melihat menembus Allah. Sudah tentu ini adalah ilusi teologis kita. Tugas teologi di masa kini, kususnya bagi kita orang-orang Kristen di Asia adalah berjumpa dan menemui Allah yang mungkin ada "di tempat-tempat tersembunyi" dari bangsabangsa dan orang-orang, agama-agama dan budayabudayanya. $^{37}$

${ }^{36}$ Craig S. Keener, The IVP Bible Background Commentary: New Testament, (Illinois: Inter Varsity Press, 2003), e-book, no page.

${ }^{37}$ Choan Seng Song, Allah Yang Turut Menderita (Jakarta: BPK GM, 2007), 
Dengan mengutip Yesaya 42:5,

Beginilah firman Allah, TUHAN, yang menciptakan langit dan membentangkannya, yang menghamparkan bumi dengan segala yang tumbuh di atasnya, yang memberikan nafas kepada umat manusia yang mendudukinya dan nyawa kepada mereka yang hidup di atasnya:

Song melanjutkan: ${ }^{38}$

Sungguh suatu konsep tentang Allah yang benar-benar universal. Allah bukanlah monopoli bangsa manapun; Allah bukan pula milik dari bangsa tertentu. Tak satu bangsapun, betapapun salehnya, dapat mengurung Allah. Tak ada orang betapapun salehnya, yang dapat menyatakan klaim secara khusus atas Allah. Memang Allah mengingat Israel tapi Ia juga mengingat orang-orang Babel. Allah mempunyai ingatan yang kuat akan gereja Kristen, memang, tetapi kesejehteraan orang-orang yang berkeyakinan dan berbudaya lain pun tak pernah lenyap dari kenangan Allah.

Tetapi apakah yang "ortodoks" dalam iman dan apakah yang "benar" dalam teologi? Tak ada ortodoksi selain ortodoksi dari Allah. Tak ada kebenaran selain daripada kebenaran Allah. Bukan apa yang kita - orang-orang percaya dan teolog percayai dan lakukan yang membuat apa yang kita percayai itu ortodoks dan yang kita lakukan itu benar. Bila Allah memanggil Koresy raja kafir itu sebagai orang yang Allah urapi, maka itulah ortodoksi. Bila Allah menunjuk dia sebagai gembala Allah maka itulah teologi yang benar.

Tetapi nabi membuktikan mereka keliru. Allah tidak terikat oleh pola apapun yang tertanam kukuh dalam kesadaran keagamaan dan nasional mereka. Malah Allah sering menerobos keluar dari pola itu dan membawa kehidupan pada suatu jenjang yang lain, memberikan umat suatu visi yang baru dan menempatkan sejarah ke dalam suatu perjalanan yang baru.

${ }^{38}$ Ibid., 66, 73, 75-75, 80. 
Iman yang meluas kendatipun terjadi tragedi dan masalah manusia berasal dari Allah yang meluas dari yang pertama sampai ke yang terakhir. Dalam pemikiran nabi yang tajam , Allah dengan jelas berkata, "Akulah yang terdahulu, Akulah juga yang terkemudian” (Yes. 48:12b; 41: 4b). Berapa jauh lagi Allah bisa meluas? bahkan Allah juga punya batas. Tetapi batas itu pada kenyataannya adalah ketidakterbatasan Allah baik dalam ruang maupun dalam waktu.

Song membentangkan bagaimana kecenderungan agama dapat dapat dengan mudah mengurung Allah. Song lebih memilih untuk melihat Allah sebagai yang tidak terbatas, yang bebas - merdeka dalam segala putusan-Nya. Nampaknya dalam pemikiran Song, sia-sialah usaha untuk mempolakan, memetakan dan mendefinisikan Allah dan rencana karya-karya-Nya. Mengutip yang dikatakan Song, Allah memang punya batas, tetapi batas itu pada kenyataannya adalah ketidakterbatasan Allah - baik dalam ruang maupun dalam waktu.

\section{Penutup}

Dari pembahasan di atas saya sangat peduli pada alih fungsi agama yang telah mengabaikan Allah. Dalam agama Allah diperkenalkan tapi agama bukanlah Allah. Sering terjadi bahwa manusia terjebak dengan sengaja atau tidak membentuk allah lain di hadapanNya, tidak peduli apakah itu dalam bentuk yang real atau konsep tertentu tentang Allah. Agama harus merdeka dari hal-hal seperti itu. Karena setiap agama adalah pengalaman yang membebaskan bukan memperbudak (band. Aloysius Pieris). Agama harus kembali ke fungsi asalnya yaitu sebagai alat Yang Ilahi untuk menjaga dan menyalurkan perdamaian. Kekerasan atas nama agama itu adalah kekeliruan, itu bukan berasal dari pada Yang Ilahi, karena itu segala sesuatu dalam agama yang penafsirannya berhubungan dengan gagasan kekerasan harus dicurigai dalam hermeneutisasi dan diluruskan agar nats penyataan Allah tidak menjadi pembenaran yang mendukung pertikaian agama.

Cukuplah sampai di sini praktik kekerasan atas nama agama, warisan pahit ini adalah hutang bersama yang harus ditinjau ulang. Karena agama bukan Allah. Walaupun harus disadari sering sekali agama menggantikan Allah. Agama harus lepas dari rantai ritualitas dan formalitas menuju ladang aksi. Aksi yang menunjukkan pada dunia bahwa Allah itu baik bagi semua orang. 


\section{Tentang Penulis}

Vik. Pdt. Parulihan Sipayung, S. Th, Studi S1 di ST'T Abdi Sabda Medan (2012), sekarang melayani di GKPS Resort Sarimatondang Pematang Siantar. 


\section{Daftar Pustaka}

Adiprasetya, Joas., Mencari Dasar Bersama, Jakarta: BPK-GM, 2002

Aritonang, Jan S., Belajar Memahami Di Tengah Realita, Bandung: Jurnal Info Media, 2007

Barr, James., Fundamentalisme, Jakarta: BPK GM, 1996

Comfort, P. W., "Idolatry", In Dictionary Of Paul And His Letters, Gerald F. Hawthorne, et.al, (ed.), Leiceister: InterVarsity Press, 1993, pp. 424-425

Coward, Harold., Pluralisme, Tantangan Bagi Agama-Agama, Yogyakarta: Kanisius, 1989

Dadang Kahmud, H., Sosiologi Agama, Bandung: PT. Remaja Rosdakarya, 2000

Effendy, Mochtar., Ensiklopedi Agama dan Filsafat (Jilid A-B), Palembang: Universitas Sriwijaya, 2000

Holladay, William L., A Concise Hebrew and Aramaic Lexicon of the Old Testament, (Michigan: WM. B. Eerdmans Publishing Company, 1980)

Jr, A.G. Honig., Ilmu Agama, Jakarta: BPK GM, 2005

Keene, Michael., Agama-Agama Dunia, Yogyakarta: Kanisius, 2006

Keener, Craig S., The IV P Bible Background Commentary: New Testament, (Illinois: Inter Varsity Press, 2003)

Keil, C. F., dan F. Delitzcch, Commentary of The Old Testament. 10 Volumes, (Edinburgh: T \& T Clark, 1866)

King, Winaton L., "Religion", Mircea Elliade , (ed.) in the Encyclopedia Of Religion Vol. III, New York: McMillan Library Reference, US, 1993.

Knitter, Paul F., Menggugat Arogansi Kekristenan, Yogyakarta: Kanisius, 2005

. No Other Name?, New York: Orbis Books, 1985

- Pengantar Teologi Agama-Agama, Yogyakarta: Kanisius, 2008

. Satu Bumi Banyak Agama, Jakarta: BPK GM, 2002

Kung, Hans., On Being A Christian, New York: Image Book Doubleday, 1968

Lefebure, Leo D., Penyataan Allah, Agama dan Kekerasan, Jakarta: BPK-GM, 2003

Magnis-Suseno, Franz., Pemikiran Karl Marx, Jakarta: PT. Gramedia Pustaka Utama, 2003

McDowell, Josh dan Don Stewart, Handbooks Of Today's Religion, London: Thomas Nelson Publishers, 1983 
Moltmann, Jurgen., God For A Secular Society, Minneapolis: Fortress Press, 1999

Okholm, Denis L., et.al, Four Views Of Salvation in A Pluralistic World, Michigan: Zondervan, 1995

Pearson, B.W.R., "Idolatry Of Jews Conception", In Dictionary Of New Testament Background, Craig A. Evan, et. al, (ed.) Leiceister: InterVarsity Press, 2000

Pittman, Don A., et.al, Ministry And Theology In Global Perspective, Michigan: William B. Erdsman Publishing Company, 1996

Ries, Julien., "Idolatry", in Lindsay James, Encyclopedia Of Religion (Second Edition), New York: Gale Cangage Learning, 2005

Saragih, Jhon Renis., "Radikalisme Agama, Antara Kekerasan Dan Perdamaian", Boby Nababan (Ed.), Radikalisme Agama, Medan: CV. Putra Mandiri, 2009

Seng Song, Choan., Allah Yang Turut Menderita, Jakarta: BPK GM, 2007

Situmorang, Jontor., The Understanding of Mispat and Sedaqah in the Book of Amos and Its Implication inIndonesia: (Ph. D, Diss. Cheonan: Hoseo University), 2004

Smith, Wilfred Cantwell., "Pemberhalaan Dalam Persepektif Perbandingan", Jhon Hick dan Paul F. Knitter (ed.), dalam buku Mitos Keunikan Agama Kristen, Jakarta: BPK GM, 2001

Snaith, Norman H., The Distinctive Ideas of the Old Testament, (New York: Schoken Books, 1969)

Stott, John., Isu-Isu Global Menentang Kepemimpinan Kristiani, Jakarta: YKBK OMF, 199

Wahid, Abdul Rahman., (Ed.), Ilusi Negara Islam; Ekspansi Negara Islam Transnasional di Indonesia, Jakarta: PT. Desantara Utama Media, 2009 